\begin{tabular}{l|l} 
Variants & $\begin{array}{l}\text { Variants } \\
\text { The Journal of the European Society for Textual } \\
\text { Scholarship }\end{array}$
\end{tabular}

12-13 | 2016

Varia

\title{
Why Do Authors Produce Textual Variation on Purpose? Or, Why Publish a Text That Is Still Unfolding?
}

Hannah Sullivan

\section{(2) OpenEdition}

\section{Journals}

Electronic version

URL: http://journals.openedition.org/variants/322

DOI: 10.4000/variants.322

ISSN: 1879-6095

\section{Publisher}

European Society for Textual Scholarship

\section{Printed version}

Date of publication: 31 December 2016

Number of pages: 77-103

ISSN: 1573-3084

\section{Electronic reference}

Hannah Sullivan, « Why Do Authors Produce Textual Variation on Purpose? Or, Why Publish a Text

That Is Still Unfolding?», Variants [Online], 12-13 | 2016, Online since 01 May 2017, connection on 2 April 2019. URL : http://journals.openedition.org/variants/322 ; DOI : 10.4000/variants.322 


\section{Why Do Authors Produce Textual Variation on Purpose? Or, Why Publish a Text That Is Still Unfolding?}

Hannah Sullivan

Abstract: Post-publication revision causes problems for both an AngloAmerican editorial tradition and genetic critics. Discussion of variance in Shakespeare, Henry James, T. S. Eliot, and Sylvia Plath shows that publication is only as much of an event as an author makes it. It need not entail a neat breach between genesis and transmission. Using Wittgenstein's notion of "seeing as", I propose that "in process" (still being composed) and "finished" (ready for transmission) are aspects of textual apprehension rather than descriptions of any individual documentary stage. Publishing a genetic dossier fixes its contour, just as post-publication revision unfixes a circulating work. Keywords: genetic criticism, manuscripts, drafts, revision, variant, variorum edition, English literature, T. S. Eliot, Henry James, Sylvia Plath, William Shakespeare.

A POET TAKES a new sheet of paper and writes in black ink, in a childish near print: "God's lioness also, how one we grow I Crude mover whom I move \& burn to love, I Pivot of heels \& knees, and of my color". Then she puts a line through the whole stanza, and through the two lines following it, and starts over. Sylvia Plath's second opening to Ariel re-envelops and alters the first attempt: "Stasis in darkness, then the ^ substanceless $^{\wedge}$ blue I Lead ${ }^{\wedge}$ Pour ${ }^{\wedge}$ of tor and distances. I God's lioness, how one we grow!"1

A novelist rereads a piece of his own fiction after its magazine publication and develops, pulls out, the central metaphor more explicitly. This process of making more explicit involves two phonological slippages, as "dived" is substituted for "lived", and "strange" for "great". "He lived once more into his story and was drawn down, as by a siren's hand, to where, in the dim underworld

1 The first of four manuscript drafts of "Ariel", reproduced in facsimile in Plath 2004, 175. 
of fiction, great silent subjects loom". This in 1893. In 1895, the first book edition has: "He dived ...". 2

A poet goes into a bookshop and opens his own recently published book. "A crowd flowed under London Bridge, so many I I had not thought death had undone so many". He changes "under" to "over" in every copy. Almost forty years later, now an old man, he is writing out the same poem by hand to raise money for the London Library. In the manuscript he adds in an unfamiliar line, "The ivory men make company between us". ${ }^{3}$

An eighteenth-century editor is puzzled by Falstaff's death in Henry $V$. Why, as evidence that he is about to die, would Mistress Quickly cite: "for his Nose was as sharpe as a Pen, and a Table of greene fields"? What could that mean? He changes "a Table" to "a' babbled". In the notes, he explains that the "nonsense" crept into the text "from the margin", where a stage direction to bring in a table "(it being a scene in a Tavern where they drink at parting)" was confused with the words. ${ }^{4}$

In all of these cases we see someone deciding between two or more textual alternatives and selecting one. All, in the broadest sense, are examples of textual variance. But the cases themselves are constituted very differently. First, who gets to decide? The original "author" or an editor? How long after the first act of composition? How quickly is the revision or emendation made, and how is it marked up, if at all, on manuscript or printed pages? By what criterion - aesthetic or veridical — can one alternative be judged superior to the others? Plath's manuscript revision happens quickly, perhaps within a few minutes or even seconds; James's post-publication revision after a two-year delay. Eliot's insertion

2 The first text was published in Scribner's Magazine in April 1893 (James 1893,611 ); the second in James's collection of short stories Terminations (James $1895,171)$. The tale was then republished with further revisions in the New York Edition of 1908-9. See Sullivan 2013, especially chapter 2, for more details.

3 This manuscript is now in the Harry Ransom Center in Texas. The online finding aid describes it as "[a] handwritten copy of The Waste Land made by Eliot for an auction benefiting The London Library contains an extra line not present in its original publication", <http://norman.hrc.utexas.edu/fasearch/findingAid.cfm?eadid=00478>.

4 See Lewis Theobald's note in Shakespeare 1733, 30. David Greetham describes it as "the eighteenth century's most famous emendation to the text of Shakespeare" $(1994,319)$. 
of "The ivory men. . ." takes forty years. Theobald's famous conjectural emendation more than a hundred. Different analytic or typological groupings of the examples are possible. In the first three cases, a writer is altering his or her own work (work that was itself, in Eliot's case, the product of collaboration); in the fourth, an editor is making the change. The first two examples are forward-looking revisions, improvements on what is there; in the second two, the intention is to regress to an original, correct, textual state, by getting rid of corruption. In Plath's manuscript and the Hogarth Press edition of The Waste Land we can see the manuscript alteration and the crossed out, repudiated alternative; in the other cases, the difference between two textual states, the "variance", is not instantiated visually on a single page.

Of my examples, only the first - an example of pre-publication revision on a manuscript, offering apparently a kind of privileged glimpse into the psychology of creation — is the stuff on which genetic criticism works. Where genetic critics agree with Paul Valéry that "nothing is more beautiful than a beautiful manuscript draft" (qtd in Deppman, Ferrer and Groden 2004, 1) and accordingly "valorize the point of departure" (Lejeune 2004, 210), studying the three-dimensional writing process itself rather than any fixed and final state, Anglo-American textual critics, who are often editors, have tended to agree with T. S. Eliot's disavowal of genetic inquiry that "too much information about the origins of a poem" may prove fatal to one's appreciation of the text itself $(1957,124)$. Only the last, an example of an editor trying to sort out transmissional corruption, is of straightforward relevance to Anglo-American editorial scholarship in the Greg-Bowers-Tanselle tradition. In fact, that editorial tradition grounded itself in the editing of Shakespeare, aiming to recover the last manuscript before book publication: "our ideal of an author's fair copy of his work in its final state" (McKerrow 1939, 18). Whether its principles and procedures work for modern texts, where actual authorial manuscripts survive, has been a subject of debate since at least the early 1980s. ${ }^{5}$

This essay aims to draw attention to the plight of examples two and three, which should be of interest to geneticists and editors, but

5 As Jerome McGann points out in A Critique of Modern Textual Criticism the more draft materials we have, the more elusive the idea of an authorial final form becomes $(1983,56-57)$. 
which have in fact tended to be neglected by both. Both are examples of authors returning to and altering their text after its publication, albeit for rather different reasons. This act of authorial return might variously be figured as harmless correction, the undoing of selfcensorship, aesthetic improvement, or unnecessarily interventionist fiddling. If we think of all post-publication changes as liable to lead to textual corruption, then it is also problematic. Which text should be reprinted, the original book publication, which has the merit of being the historically received, "authentic" version, or the revise, whose claims to being "final" may seem undermined by not being the only final version? In the case of Henry James, the vast majority of reprints of the major, revised novels and tales, use the first book text, not the New York Edition text. ${ }^{6}$ Why would an author introduce variation into their own published work on purpose? Or, to put the question the other way round, why publish a text before its genesis is complete?

In the analytically "easy" examples, one and four, composition and transmission (via book publication) happen in the temporally expected order. Revision and authorial equivocation (if revision happens at all) is restricted to the private sphere of drafting; everything that happens to a text after first publication is the responsibility of an editor. If the reading "table" were incorrectly interpolated into Henry $V$ from the margin, it was a printer's doing. And because Plath committed suicide only a few months after drafting the poem "Ariel", the poems in the Ariel collection were selected and ordered by her ex-husband, Ted Hughes. In his introduction to Plath's Collected Poems, he explains that to produce his edition he had to turn away from the seductive manuscript pages - "handwritten pages [. . . ] aswarm with startling, beautiful phrases and lines, crowding all over the place" $(1989,17)$. There is a poignant blurring here between the poems' content, their manifestation in manuscript, and their heightened status as a dead wife's last speech act. Plath's handwritten pages are crowded with life, "aswarm" like the bees she writes about. ${ }^{7}$ It is her death that closes

6 See Adrian Dover's helpful guide to "Reprints of Henry James Novels" (Dover 2003). The American, for example, has been reprinted in thirteen editions since 1949, but only two editors selected the text of the New York Edition.

7 Within this vitality is the threat of menace. "The Swarm" is a poem of fierce sexual jealousy, threatening reparation. The icy comparison in "It seems 
down the possibility of further genesis, leading to publication and the congealing of fluidities into a "final form". 8

If all revision was performed in private, in manuscript, and if all post-publication changes were posthumous corruptions, then these two schools could account, between them, for all problems of textual variance. Genetic critics could tease out the significance of manuscript alternatives, while final-intentionalist editors posed and answered a practical question, "What reading should the editor print?" For the former, a "variant" might be an interesting path taken or not taken in successive versions; for the latter, a variant would be not much more than an error. Genetic criticism would be the study of authorial manuscripts and textual criticism would work with printed books. So far, so simple. But authors do not always manage the instant disappearing act that, Roland Barthes tells us, is the price of readerly reception: "the birth of the reader must be at the cost of the death of the Author" $(1977,148) .{ }^{9}$ The strategy of Barthes' 1967 essay is to turn the "Author" into a kind of mayfly, "born simultaneously with the text" and expiring on the same day $(1977,145)$. His aim is to dismantle the old idea that an author is a text's past, an authoritative parent who nourishes it, but, in so doing, he also excludes the author from the text's future.

Barthes' model of the evanescent scriptor works for both Shakespeare and Sylvia Plath. By the time Ariel and the First Folio of Henry V (a play with a "bad" quarto) were published, the original authors were dead. In focusing on the living authors in examples two and three, I aim to shed light on two fantasies - really they are fallacies - that both genetic critics and traditional editors are in danger of entertaining.

First, the idea that publication is a singular event, a complete transfer from author to reader. In emphasizing the distinction between what Louis Hay calls "a plurality of virtual texts" and a single "constituted text" $(2004,22)$, genetic critics invest the

bees have a notion of honor" (Plath 1989, 217) makes uncomfortable reading even for those of us who are not Ted Hughes.

8 Hughes notes that Plath was "forever shuffling" her poems' order (1995).

9 Barthes was right to deny that "book and author stand automatically on a single line divided into a before and an after" $(1977,145)$. It is his solution, which replaces the real author with an ephemeral signatory, a mere designation on a book cover, that is wrong. 
moment of publication with almost alchemical significance, as if it is there, in that single instant, that a text becomes public rather than private, fixed rather than fluid, single rather than plural, cooked rather than raw, après rather than avant. Anglo-American editing has the same fetish; once again, the first falling of the plates is the Fall from grace into error, as the hypostasized "ideal of an author's fair copy of his work in its final state" (McKerrow 1939, 18) turns into a printed book made by someone else. In both cases, book publication is invested with a numinous importance and finality that is, at least sometimes, hardly warranted. What does it mean in oral culture for a poet to "publish" a poem? What does it mean to publish a novel digitally? Communally? The terminology of "bon à tirer", like Greg's rationale of copy-text, derives from a set of material practices (book publishing) specific to a period of about four hundred years, after Gutenberg had made mass reproduction of a text possible, but before the typewriter, personal computer, photocopier, and internet had made it cheap. Within this material culture, first book publication often corresponds to the moment that an author relinquishes interest in a project (thereby ceasing to revise it) and happens to be the mechanism by which transmission of the text begins. But this is by no means always the case. Shakespeare's plays picked up variation in performance, before any text was printed; so too did Ulysses, in Joyce's multiple sending of proof. Henry James, on the other hand, extended his story's genesis past the point of publication. The more basic and useful meaning of publish is simply "to make public". This needs neither to be a single event (e.g. something that happened on 2 February 1922) nor a visually transformative one (e.g. the rendering of handwriting into print). Publication is only as much of an event as the author makes it. Nor, under modern European and American intellectual property law, can it effect more than a material transfer. Even if a writer composes a letter and sends it "off" without retaining a copy, it is only the physical text that remains entirely in the reader's possession, under the common law of personal property. ${ }^{10}$ The right to the

10 In US law this is codified as "ownership of a copyright, or of any of the exclusive rights under a copyright, is distinct from ownership of any material object in which the work is embodied", <http://copyright.gov/title17/92chap2. html>. The UK copyright act of 1911 identifies copyright simply with authorship: "the author of a work shall be the first owner of the copyright therein", 
text "itself", including the right to alter or suppress it, remains with the original author; in French law this is expressed as the "incorporeal" right. ${ }^{11}$ And usually, pace Barthes, authors manage to survive the publication of their works. In a legal sense, then, "the birth of the reader" is achieved only some fixed number of years after the death of the author, when the work passes into the public domain. ${ }^{12}$

The second fallacy, related to the first, is the idea that composition and transmission are mutually exclusive activities, stranded on either side of publication. Of course, transmission and composition are not the same thing. But the difference is one of kind rather than precedence. My suggestion is that we distinguish rigorously between transmissional corruption and authorial revision, without making assumptions about the temporal order in which they happen or the way that they present visually. To make this distinction easier, I think it is helpful to retain the traditional AngloAmerican term "variation" to refer to the process of corruption that happens after circulation has begun. Variance, by contrast, can be used to refer to textual alternatives that arise not by error, but from genuine undecidability (even if that undecidability is resolved in turn).

Anglo-American editing, which modelled itself after the higher prestige study of Classical and Biblical texts, began as an attempt to deal with variation consequent on post-authorial transmission. ("Post-authorial" is not a point of principle, merely the nature of the surviving documents, or witnesses.) In this tradition, a variant is regarded as a deviation or error from the original, invariant text. The task of the editor is to restore this original text by selecting the correct, intended reading from the ramifying set of alternatives. W. W. Greg's alarmingly algebraic essay The Calculus of Variants: An Essay on Textual Criticism explains the problem clearly: "the process of transcription is characterized by variation, and it is only

$<$ http://www.legislation.gov.uk/ukpga/Geo5/1-2/46/section/5/enacted>.

11 Article L111-1: “L'auteur d'une oeuvre de l'esprit jouit sur cette oeuvre, du seul fait de sa création, d'un droit de propriété incorporelle exclusif et opposable à tous", <https://www.legifrance.gouv.fr/affichCodeArticle.do?i dArticle=LEGIARTI000006278868\&cidTexte=LEGITEXT000006069414> ("The author of an intellectual work spirit enjoys on this work, from the mere fact of its creation, an exclusive right to intangible property enforceable against all").

12 Under the Berne convention, the norm is 50 years; in 1995, this was extended to 70 in the UK. 
in the process of transcription that variant readings arise" $(1927,8)$. Sometimes - particularly in the case of "creative" or strong conjectural emendation (like "a' babbled" for "table") — the editor has the opportunity to display ingenuity and skill. But on the whole this tradition sees getting the text right as a matter of legal and ethical importance. Fredson Bowers explains: "As a principle, if we respect our authors we should have a passionate concern to see that their words are recovered and currently transmitted in as close a form to their intentions as we can contrive" $(1975,305)$. Most of the interventions it makes are quite simple, explicable by rules such as lectio difficilior potior. This is because variation is inevitable, no less - but also no more - than the outcome of transmitting information. It has nothing specifically to do with book publishing or print, or with the relinquishing of authorial control. Stagings, oral performances, and manuscript transcription also produce corruption (gabbled and omitted lines, slips of the pen quickly corrected, etc.).

Literary critics sometimes behave as if pre-modern texts show no evidence of revision but are inevitably corrupted, while modern texts have complex geneses but are transmitted perfectly. Neither of these things is true. The error introduced into a message is a function of the number of times it is transmitted, but frequent simultaneous transmission (e.g. a poem published on multiple separately managed webpages) may be more problematic than slow linear transmission (e.g. a poem reprinted in a new book edition every fifty years). There are many possible causes for transmissional variation in contemporary literature: premature death (David Foster Wallace is an important recent example); faulty typesetting and proofreading (The Waste Land); self-censorship; or, in computer-generated texts, from OCR errors in translating scanned images into text. At the same time, the fact that genetic criticism of Shakespeare is not possible (because no authorial documents survive) does not mean either that he never revised or that we have no evidence of his revisions. In the eighteenth century, Pope thought that the differences between the Bad Quarto of Henry $V$ and the "extremely improved" First Folio were primarily evidence of revision (Pope 1751, 401). ${ }^{13}$ By the later eighteenth-century, the corruption theory predominated. In the 1980s, revisionism (now

13 Alexander Pope, "Preface to the Works of Shakespear," The Works of Alexander Pope Esq. Volume 6 (London: J and P Knapton, 1751), 401. 
"new revisionism") came back into favour, with the suggestion that Shakespeare "abridged" the Quarto for political reasons, in an act of "tactical retreat" (Patterson 1988, 41; on the new revisionism more generally, see Lesser 2004). We know that corruption must have occurred in the transmission of Shakespeare's plays (because it is a law of information), but there is no a priori reason to assume that the significant differences between Folio and Quarto texts are a result of confusion and corruption and not purposive revision.

In my second and third examples, we see first Henry James and then T. S. Eliot returning to the scene of the crime, continuing to make meaning by interacting with their texts in published form. Eliot first writes on his already published book, and then writes out his almost forty-year old poem. In doing so, he produced a document which looks ironically like the authorial "fair copy" which Anglo-American editors have taken as their lodestar. How James made his revisions for the first book edition of "The Middle Years" is not certain. For its second post-publication revision in the New York Edition, we know that he wrote around the printed pages of his earlier fiction, which had been pasted up on to blank sheets of paper with extra-wide margins. ${ }^{14}$ In both cases, the material documents produced in the pursuit of continued genesis are rather peculiar. But the textual import of this rewriting on is quite different in the two cases, as a more detailed discussion will show.

When Eliot slipped into a bookshop to correct a mistake in the Hogarth Press text of The Waste Land, he was making an alteration to a poem with a vast creative hinterland. The pre-publication manuscripts and typescripts of The Waste Land, published in facsimile in 1971, have now been thoroughly absorbed into critical discussion. As Christine Froula observes, critical readings "cross easily between the 1921 and 1922 texts" $(1996,313)$, and it is one of the few English texts where genetic work has become the norm. And, compared to the richness and strangeness of the manuscripts, this story of alteration is tiny. In fact, it is nothing more than a charming textual vignette about Eliot's self-described "abominable proofreading" (2009b, 202-203). ${ }^{15}$ The Criterion publication and

14 In a review of Philip Horne's Henry James and Revision (1990), Margaret Anne Doody comments that "[t]he tempting blank of these margins was his downfall: invited to fill the space, he more than filled it" $(1991,16)$.

15 Eliot apologizes for his poor proofreading in a letter from $c$. 3 September 
first American edition did not contain the mistake, so there was never any doubt about what the correct reading should be. In a bibliographical sense, we have to record "under London Bridge" as a textual variant, but I would suggest that we exclude it from a discussion of variance in the poem. ${ }^{16}$

Eliot's second alteration is also small, but it is, at least potentially, an example of meaningful variance - a moment where someone has paused to decide. Until 1971, when the drafts of The Waste Land were published, Eliot's insertion of the line "The ivory men make company between us" into the London Library manuscript must have seemed confusing. Was he expressing a new final intention for the poem in 1960? Had he decided that this mysterious reference to a game of chess was to be added to his text? Lawrence Rainey notes that the line is not in the 1962 Mardersteig edition and that Eliot referred to this edition as the standard text (see Eliot 2005, 51-52). After 1971, however, a richer hermeneutic explanation was possible. Christopher Ricks says that "what makes the line so cutting is the dark double-edgedness of 'between"' $(1988,212)$, but his explanation of the line's cutting edge and its dark removal is based on another fact: the line was in the original manuscript but deleted at Vivienne Eliot's insistence. This, at least, is Valerie Eliot's claim in the notes to the facsimile. In the draft itself, Vivienne has written a very faint "Yes" next to the line, which is not crossed out (Eliot 1971, 12-13, 126). Is it possible that only after the death of his first wife, Eliot felt able to reintroduce a line that she had deleted? C. J. Ackerley thinks the line a "too-obvious reference to Bertrand Russell, whose role in the Eliots' early married life was insidious" $(2007,52)$. If Eliot was undoing a bit of censorship he resented, then our future editions of the poem should include the line, which also helps to make sense of "The Game of Chess" as a title. ${ }^{17}$ It would be part of the author's final intention for his poem. But I think it is more likely that he added the line to make the copy more valuable,

1923 to Virginia Woolf, his printer, thanking her for the publication (Eliot 2009b, 202-203).

16 Jim McCue notes that Eliot did not seek republication of the Hogarth edition, and expresses surprise that he "failed to spot so gross an error" as "under" for "over" $(2012,19)$.

17 After the publication of the drafts, Helen Gardner agreed that "the title has rather lost by Eliot's excision at his wife's request" $(1972,23)$. 
by allowing it to carry a little piece of hidden genetic information. The manuscript of The Waste Land had not, of course, yet been published and even Eliot himself would not have known that it was still in existence. In the age of mechanical reproduction, it may be that Eliot was increasing the value of the fair copy manuscript by making it not merely a copy, but a kind of limited edition or one-off.

Given the ferocious indecisiveness that marked the pre-1922 history of both The Waste Land and Ulysses, one might have expected that their authors would also have been avid post-publication revisers. But this was not really the case. Besides the restoration of this single line, made after Vivienne's death, Eliot did not carry on working on his poem; by November 1922, it was already "a thing of the past so far as I am concerned" (Eliot 2009a, 786-87). After the publication of Ulysses, Joyce - not to put too fine a point on it - lost interest in it. But other late nineteenth- and early twentieth-century writers - Whitman, Yeats, Auden, Moore - were extensive postpublication revisers. There is no necessary relationship between the amount of revision authors do during the earlier and later stages of composition. Where Joyce turned over the preparation of the 1932 Odyssey Press edition of Ulysses over to Stuart Gilbert, W. H. Auden made extensive changes, both corrections and revisions, on the material pages of his own copies. ${ }^{18}$ Nor is it always easy to differentiate between willed revisions and unwanted corruptions produced in transmission. It becomes even more complicated when we begin to suspect that a writer is colluding with and profiting from what Vicki Mahaffey terms "volitional error" (1991, 183). Ezra Pound's "Homage to Sextus Propertius" gains its poignancy partly from Pound's exploitation of a basic law of information theory: corruption is inevitable, and no such thing as a perfect translation or even a perfect copying is possible. Christine Froula has written well about Ezra Pound's hospitality to transmissional error; his habit, in fact, of reprising it, reworking with it left in, and making it of genetic significance (see Froula 1984). We see a similar toying between intended and unintended (censored) meaning in

18 Using the word "revision" in a rather old-fashioned sense, the Odyssey Press edition had "the bold statement on the verso of its title-page that "The present edition may be regarded as the definitive standard edition, as it has been specially revised, at the author's request, by Stuart Gilbert'"'. Evidence suggests, however, that Gilbert did not edit the text (see McCleery 2006). 
Ginsberg's line in Howl "with mother finally *****”, which he let stand in the poem despite its frank publication of other obscenities, and which he also read aloud as "mother finally asterisked". The 1955 draft typescript has "with mother finally fucked". ${ }^{19}$ The revision of "fucked" to "******" is not an act of self-censorship, so much as a knowing dig at a censorship culture.

A kind of magical thinking around publication - the investment of this "far-off divine event" with properties it lacks - leads to other analytical biases or problems. Both genetic critics and Anglo-American editorial traditions are apt to place an unwarranted degree of emphasis on the visual "look" of a document, as if the number of erasures or the variety of different coloured inks or the expense of the paper could tell us whether it is (a) finished or (b) public. Broad generalizations can certainly be made within historical periods but, like all generalizations, they exist to be contradicted. In the early twentieth century, for example, a typescript with handwritten marginalia often represents something close to "the author's final intention"; the next stage, the galley proof with handwritten marginalia, will be the last document on which the original author can easily make changes. But take again as counter-examples the case of The Waste Land and Ulysses. For Joyce, typescript quickly became an exciting new surface for writing anew, and so what was intended as a document of transmission begins, in Gabler's phrase, "to acquire the status of documents of composition"; from this "the question arises of how far the authorial presence affects, and penetrates, their basic level of transmissional transcription" (Gabler 1986, 1892). ${ }^{20}$ The Ulysses typescripts, we might say, are draftier than they look. For Eliot, by contrast, a major benefit of duplicate and triplicate typescript was circulation: it

19 The second draft, the first containing the phrase, has "and who returned later truly bald with [crossed out, unreadable] mother finally fucked", and the third has the phrase pulled forward to the beginning of the strophe, "with mother finally fucked, and the last book thrown out of the attic" (Ginsberg 1987, 27, 31).

20 Hans Walter Gabler's edition of Ulysses is suspicious of the legalistic primacy attributed to the 1922 edition ("the legal act of first publication did not validate the actual text thereby made public to the extent of lending authority to its high instance of corruption" [Gabler 1986, 1892]), although he retains the term publication for an event that happened on 2 February 1922. 
allowed him to communicate a poem on which he was stuck to a single, best reader ("il miglior fabbro") without losing his own copy of it. He told Conrad Aiken in the winter of 1921-22 that he went home every evening with the hope of writing but "the sharpened pencil lay unused by the untouched sheet of paper" (Aiken 1967, 195). Most of the extensive writing on the typescript is Pound's, not Eliot's, and functions as instructions for strategic deletion rather than adding new material to the poem: it is more published, more public, than historical norms would lead us to expect. Eliot had got almost as far as he himself could get with the genesis of The Waste Land when he sent it to his friend to be "attacked" (see Eliot 1971, 54-55).

Alternatively, consider the relative privacy of a handwritten poem enclosed in a letter. For most poets in the 1890s this would not be textually significant, but, for Gerard Manley Hopkins, enclosing a poem in a letter to Robert Bridges was publishing it, as he himself recognized. When Bridges criticized "The Wreck of the Deutschland", Hopkins explained: "I cannot think of altering anything. Why shd. I? I do not write for the public. You are my public and I hope to convert you" (letter to Robert Bridges, 21 August 1877, qtd. in Roberts 1995, 51). The word "altering" registers that the text has become shared, even as it insists that intellectual property rights accrue to the original author. This handwritten poem is at a later genetic stage than the proofs of Ulysses. Sometimes appearance tells us nothing at all. When we read a text on a webpage or buy a book through Amazon Kindle, it is almost impossible to know how many "updates" there have been, or to predict how many more there might be. In an individual user's Kindle Library, an innocuous information badge marks the arrival of a new version: "update available". If the settings are correctly adjusted then "the previous version will be replaced with the corrected version" whenever possible.

The instant and costless substitution of a new version for an old was not possible for Henry James. But the writer-hero of "The Middle Years" fantasizes about doing precisely that.

Dencombe was a passionate corrector, a fingerer of style; the last thing he ever arrived at was a form final for himself. His ideal would have been to publish secretly, and then, on the published 
text, treat himself to the terrified revise, sacrificing always a first edition and beginning for posterity and even for the collectors, poor dears, with a second. (James 1895, 181)

Given that Dencombe has no interest in being published for its own sake, no family to support (we are told that both his wife and child are dead), and no apparent economic necessity, we might wonder why he publishes his book at all. If his fantasy is endlessly to defer reception, and endlessly to revise then why, the genetic critic might wonder, does he not stick to manuscript?

The answer, which a close reading of the story affords, is important for understanding Henry James's own process of postpublication revision. It also speaks more generally to the twin questions motivating this essay, by shedding light on the paradoxes and pleasures, especially the paradoxical pleasure of self-sacrifice, that post-publication revision affords. In particular, it draws attention to the role of the reader in constructing textual variance.

Many of us will have had the experience of "seeing" a mistake in a written submission only when it is too late (because the article is published) or nearly too late (because it is expensive to make changes in proof). Why do we not see the error earlier? Something about the visual estrangement into a different medium - a different typeface or file format or onto a different type of paper - provokes rethinking. Dencombe's fantasy may seem, to begin with, as if it is the creative version of this; he wants to "publish secretly" and then revise on the (non-circulating) publication, pricking "lights" that, perhaps, he could not have seen before. But, besides being a "passionate corrector", James tells us that he is also, more obscurely, "a fingerer of style". What can this second phrase mean? Besides a vague penumbra of autoeroticism, there is, I think a more materially precise meaning. Isaac Pitman's A Manual of the Typewriter, first published in the same year as James's short story (1893), contains a long section on "The Method of Fingering". It advises how many fingers to use while typewriting (three, preferably) and where to position them on a QWERTY keyboard for maximum efficiency. As this layout of this keyboard became familiar, the correct method of "fingering" it fell out of discussion. In 1893, however, at the beginning of the age of the typewriter, I think James's unusual noun is carefully chosen. 
For its earliest users, as Pitman's manual explains, "typewritten matter compares with print, and it will always suggest that comparison to the reader. It requires, therefore, to be at least as free from errors and irregularities of all kinds as print usually is" (1893, 8 ). By typing up a short story oneself (or having a typist do it for a fee), the writer of the 1890s was able to translate the private space of the manuscript page into the visual iconography of print. This new possibility must have been very strange for authors who had grown up with a rigid divide between draft and book, manuscript and print. James's coordination of the two activities - correcting and fingering - suggests that Dencombe is an avid reviser and a typist or perhaps, even, an avid reviser because a typist.

This gets a little further towards understanding the masochistic structure of Dencombe's fantasy. What he wants is not "to publish secretly", but to correct his already published texts in plain view. In other words, the problem is not his inability to render his texts into the form of a published book without circulating them, like a programmer who develops internet content without letting it go live. The embarrassment of publication, the very publicness of it, seems to be the point. From the beginning of "The Middle Years" James blurs the language of authorship with the idiom of social, even romantic, intercourse. The author's interest in rereading and revising his novel doesn't happen despite his book being abroad in the world: it comes about as a consequence of it. He receives his new volume in public, as he recovers at a health resort, and it is delivered by a "sociable country postman" (James 1895, 167). But because he is now middle-aged, he is unable, James tells us, to feel any intrinsic pleasure at being "just out" — a phrase drawn from the debutante's coming-out ceremony. Most blatantly of all, the book's cover is "duly meretricious", a self-prostituting "red" (170). He begins reading and then, of course, revising his work as he watches a "a group of three persons, two ladies and a young man" on the beach below him (173). The young man himself is also reading a novel. It will turn out to be the very same novel that Dencombe is revising. But, at first sight, he is unable to recognize his own book. Proving how completely his work has been commoditized in the marketplace, it turns out to have exactly the same "catchpenny" binding as other novels in "the circulating library" (169). It is only when Dencombe fails to recognize his own novel in another 
reader's hands that it is transformed into an object of desire: "the gentleman had his head bent over a book and was occasionally brought to a stop by the charm of this volume, which, as Dencombe could perceive even at a distance, had a cover alluringly red" (168). It is from this set of mistaken identities, both personal and textual, that the story's "death of the author" plot develops.

Dencombe's fantasy is of continuing his book's genesis after the point of initial publication. In an important sense, the ideal text that he dreams of creating remains resolutely private. He is not trying to garner feedback on the book he has published, and he in fact continues revising in the face of strong opposition from his rather ideal reader, Doctor Hugh. At the same time, the act of revision itself is structured socially. It is because his book has become a "public" object of circulation and social exchange that he interests himself in it once again. His motivations for revision are, in every sense, "impure". He wants to be caught in the act of revising in print and, when he is, he stammers "ambiguously" and faints, "stretching out a hand to his visitor with a plaintive cry" (James 1895, 182).

In some ways, Dencombe's desire to keep revising is an enjoyment of what James elsewhere, in the Preface to The Golden Bowl, called "the muffled majesty of authorship": anyone, including the ardent young reader Doctor Hugh, can write about this novel but only he, as its original author, can continue to write on it (James 1984, 1323). In fact, before he realizes that Dencombe is a novelist, Doctor Hugh understand his markings on the page as a rather aggressive and strange act of editing, "I see you've been altering the text!" (James 1895, 181). On the other hand, inevitably, the reappropriation of textual control also leads to a diminution of it. If post-publication revision leads to a new text, then, instead of any single text exercising full authority, the reader is given a choice between two alternative versions. It becomes reasonable for someone else to produce a third text or variorum edition to account for the differences. This "third text" threatens the integrity of authorship, the ontological primacy of any single text.

In the everyday sense of the word, we might see an element of masochism in all forms of revision that take too long, are economically wasteful and threaten to produce something superfluous, or even something plain old worse. As Valéry observes, in his lovely comments on rereading his own work, no temptation is more fruitful 
than the self-denial that comes in denying one's earlier intentions primacy..$^{21}$ But the Jamesian version of revision is masochistic in Deleuze's more precise sense of the word. ${ }^{22}$ Gratification is delayed endlessly, and the iterative process of reworking extends infinitely; in the end, the suspense itself becomes the primary form of pleasure. The act of communication between writer and reader, instead of being perfected, is endlessly deferred. Dencombe's revisions cause problems for Doctor Hugh because he is unable to begin reviewing and responding to a book that won't stay fixed. Henry James's readers were, sometimes, equally irritated by his inability to leave alone. But when Edmund Gosse complained that James was achieving nothing more than the "dribbling of new wine into the old bottles" by revising for the New York Edition, the author's response was violent in the extreme: "The only alternative would have been to put the vile thing [. . .] behind the fire and have done with it!" (Gosse 1922, 47).

By the time James came to put the New York Edition together he was in his sixties. But the language James uses to describe revision as an endless process of genesis leaves open the possibility, in principle, of another round. In the Prefaces, he represents his own process of post-publication revision variously as a matter of imaginative renewal, self-pleasure, anxiety, intense excitement and some shame. His former texts are described as intensely enjoyable to reread but also as objects of pity, even shame: Roderick Hudson calls to mind a painting "fatally faded", "blackened or 'sunk"' after the ravages of time and weather; The Tragic Muse a grotesque body barely contained by "the precious waistband or girdle" intended to give it form; The Golden Bowl an "uncanny brood" of prematurely aged children with "wizened faces" and "grizzled locks" (James 1984, 1045, 1108-1109 and 1331). If rereading is accounted for in terms of pleasure (Dencombe's "living"/"diving" back into his own tale), rewriting seems to be necessitated by the abject, aged state of these textual bodies. The sensual, tactile language of these

21 "Il n'est pas de tentation plus cuisante, ni plus intime, ni de plus féconde, peut-être, que celle du reniement de soi-même" (Valéry 1919, 9-10) (“No temptation is keener or closer to the heart, and none, perhaps, is more productive than that of denying oneself") (Valéry 1972, 65).

22 "Waiting and suspense are essential characteristics of the masochistic experience" (Deleuze 1989, 70). 
descriptions is remarkable in a novelist often described as "cerebral rather than physical, passive rather than active" (Halperin 1996, 22). The images are drawn from a prodigal variety of semantic sets, but have in common a repeated fascination with neat (sometimes too neat) surfaces knitting over depths, and creation and recreation are both described as a form of puncture. Dencombe "pricked" (James 1895, 181) the text as he reread his already published book in "The Middle Years". But the same word is also used in the New York Edition Prefaces to describe the very beginning of the genetic process, the initial "germ" of an idea. In the Preface to volume 10, James speaks of "the stray suggestion, the wandering word, the vague echo, at touch of which the novelist's imagination winces as at the prick of some sharp point: its virtue is all in its needle-like quality, the power to penetrate as finely as possible" $(1984,1138)$. Throughout these descriptions, tenderness mixes with cruelty: it is not only post-publication revision on a printed page, but the whole cycle of production, that is described as a kind of puncture wound. In talking of revising "The Middle Years" itself, the language of masochism is more explicit still, the text both patient and victim: "I scarce perhaps recall another case [...] in which my struggle to keep compression rich, if not better still, to keep accretions compressed, betrayed for me such community with the anxious effort of some warden of the insane engaged at a critical moment in making fast a victim's straitjacket" (James 1984, 1238).

The genetic critic who takes the moment of "bon à tirer" as an end and the Anglo-American editor who tries faithfully to reconstruct an author's final intention are both operating as if writers were rational agents who always acted in their own (or their text's) best interests. In the broadest terms, they assume that, however painful or protracted or confused the process of textual genesis is, it will eventually come to an end so that the text can circulate and be read in printed form, so that it can endure. But not all writers are rational about their own textual best interests all of the time. Sometimes their behaviour threatens to be self-defeating. Dencombe's postpublication revision, like James's, creates more problems than it solves. Not only does it take up a great deal of time that could be devoted to new composition, but it also threatens the very stability of the object it seeks to fix. Despite the self-proclaimed finish of the New York Edition, most contemporary editions of James's texts are 
based on the first book printing, often with substantial lists of variants provided in notes or the appendix.

James's most careful readers spend an inordinate amount of time not on reading the novels in their final form, but on teasing out the fissures between printings, as if these points of difference - the elaborated metaphor, the modified gesture - will produce a finer and fuller "reading". And James is not the only modern writer whose work comes to us with an extensive and provocative list of authorially introduced variants. The Variorum Edition of W. B. Yeats's poems (1957) gives us a "text" that is as uncertain - if uncertainty is the measure of ramifying possibilities for reprinting - as that of many pre-modern authors. Compared to the beautifully designed books that Yeats oversaw in his lifetime, it is also an ugly, unwieldy book, offering a scattered set of alternatives rather than a clear reading text. The editors of the Leaves of Grass variorum assert that their edition, a meticulous history of authorial changes of mind, "is Leaves of Grass as the serious student has long wanted to have it" (Bradley et al. 1980, ix). But it is, quite patently, not Leaves of Grass as Whitman wanted to have it. Sylvia Plath left the manuscript that became Ariel on her desk, but it is not quite, as Linda Wagner-Martin has it, a book of poems "ready for publication" (Wagner-Martin 1997, 7). ${ }^{23}$ Among other things, although the cover page of the typescript bears the neat legend ARIEL and Other Poems by Sylvia Plath, the next sheet (which could have been removed) bears witness to alternative intentions: "DADDY" is written by hand in large black capitals to replace the base layer of typescript, "THE RIVAL and Other Poems". An intermediate intention has "A Birthday Present" (Plath 2004, 94-95). The typescript that follows contains multiple small changes to accidentals of punctuation, as well as further uncertainty about titling ("The Courage of Quietness" or "Shutting Up"?) (Plath 2004, 97-98). But these are equivocations compared to the more major problem. Despite making a careful list following the contents of where individual

23 Linda Wagner-Martin draws attention to the alternative titles in a footnote, saying that "the collection earlier was titled The Rival, The Rabbit Catcher, A Birthday Present, and Daddy" $(1997,7)$. But if Plath left these scribbled-over sheets in the final packet on her desk, she was intending to communicate at least something - perhaps nothing more than a more felicitous new choice of title - by showing her own equivocation. 
poems had been accepted for publication, Plath had not made plans for the publication of the whole. It would be hard to argue that she was complicit in the decisions Hughes made about the poems' arrangement even if, in a legalistic sense, she "intended" him to be her executor by dying intestate and still married. His own letters organizing publication assume an editorial authority that in fact he lacked. The document she left behind led to Ariel but also, inevitably, to Ariel: The Restored Edition, which "exactly follows the arrangement of her last manuscript as she left it" (Frieda Hughes 2004, ix).

Because publication is not in fact a single event (like 2 February 1922) with a discrete before and after, material that was once archival and genetic does not always remain so. The dividing line between avant-texte and text is always subject to renegotiation. The publication in the second half of the twentieth century of so many of the draft materials of modernism shows not only that the private can be made public, but that the multiple can become singular. If a published text's claim to "authority" evaporates in the face of subsequent authorial revision, a draft's claim to be "multiple" and open, a perpetual site of genesis, may be foreclosed by publication. Valerie Eliot's facsimile of The Waste Land drafts claims to be no more than membra disjecta, false starts, rough papers, loose ends. But it also circumscribes the possible size of the archive by making implicit claims to completeness: there may be many possible variants of The Waste Land within its covers, but there are none beyond it. It is troubling to imagine how a new scrap of material - an object belonging to the flotsam and jetsam mode of the archive could be incorporated into its covers. ${ }^{24}$ Now that we are at the point where critics of The Waste Land cross easily and freely between the "final" 1922 version of the poem and the manuscript materials, both of which they have on their bookshelves or even on course syllabi, we may wonder whether mass reproduction has withered the archival, provisional, fluid quality that early scholars found in the drafts. ${ }^{25}$

24 John Haffenden argues that an early version of the Fresca couplets "need to be instated alongside the bulk of the Berg drafts in any future edition of the Facsimile", but this is highly unlikely to happen $(2007,23)$.

25 Linda K. Bundtzen describes Plath's "textual body" as existing in a dusky limbo in the Smith College Library Rare Book Room (2001, 5). Did this 
Genetic material sitting unpublished in a distant archive retains its aura, remains in a sense "alive". But, once published, it enters inevitably into the postlapsarian world of fixity. And yet this "fixity" is mutable in turn: authors can return to published texts and dissolve them back into the chaos of genesis; creative emendations allow editors to do the same thing. The creators of the Samuel Beckett Digital Manuscript Project go some way to recognising this when they explain their work as "both a digital archive and as a genetic edition" (Van Hulle and Nixon 2015). The archive and the edition are, indeed, not opposites. But their characterization of the relationship between digital archive and genetic edition as a "continuum" is not quite right either: it suggests that at one end, like the colour yellow, we have "pure archive", and at the other end, like blue, the "pure edition", and, in between, in various hues of green, some slightly edited archive or some slightly messy variorum edition.

The figure of the continuum implies that textual variance exists only "out there", in objects. But variance is never found in any individual document or reading; it is a second-order measure of the difference between readings. In the same way, no individual piece of writing - whether a burnt piece of paper full of many interlinings and crossings out, or an inscription in stone - is, in itself, a draft or a final form. This is because the property of "being unfinished" or "being finished" is not a property of any single piece of paper or a stone slab, seen by itself, but a quality that can be attributed only relationally. Invoking Wittgenstein's duck/rabbit, I want to suggest that the relationship between archive and edition is, rather, one of duality. We can choose to see any given textual document or archive under different aspects, just as the peculiar duck/rabbit drawing can be seen now as a duck, now as a rabbit (Wittgenstein 1953, 194e-202e; II.xi ). The rabbit is not the opposite of the duck, but nor are the two at different ends of a continuum: the figures are congruent. To begin with, only a single perception will be available. One starts by seeing either a duck or a rabbit. But some observers will then come to a second perception, which is the possibility for alteration between the two things, or the ability to "see something as something". We can also imagine someone

end three years later when Faber published the original arrangement? 
without the imagination to "see something as something" who is stuck always with a picture of a rabbit.

To go back to my original four examples - which could be expanded with countless others - it should be clear that all of these examples can be viewed genetically or editorially, from the point of view of variance (and. . . and. . .) or in search of the invariant (or. . . or. . . ). One mode is combinatorial, the other is selective; one is diachronic and narrative, the other is synchronic and analytic. Henry James's short story "The Middle Years" was finished in 1893. It remains finished for, say, a book historian writing about the intended audience of Scribner's magazine in 1893, or for the first-time reader who reads a plain text online translated from this format. But in 1895, it was not finished for Henry James, and it remains unfinished, a first attempt, when placed alongside the later text(s) on a library table or in the comparative context of a variorum edition. Plath's marked-up typescript was taken by Ted Hughes as a provisional draft towards the Ariel he published; for others, it is "a fair copy, made by the author herself, of the work as she finally intended it". Eliot's 1960 addition of the extra line to The Waste Land manuscript is both a story about repression and the removal of self-censorship and an opportunity for editorial decision-making.

Each documentary stage develops its meaning in relationship to the others, and the text as a whole is constructed from the sum of its stages. But the hermeneutic circle is not in practice closed, because new documentary evidence can always show up. "The ivory men make company between us" was added to The Waste Land that readers had in 1960; eleven years later, a whole lot of other discarded lines and genetic material became part of its history.

Wittgenstein describes as aspect-blindness the kinds of aesthetic conversations that insist on seeing one way only: "You have to see it like this, this is how it is meant" (1953, 202e). To commit oneself ahead of time to one method of textual interpretation (seeing "in terms of accuracy and error" or in terms of meaningful variation) is, I believe, to run the same risk of dogmatism. This is not to say that the genuine apprehension of a duality is very easy: to understand the rabbit/duck means not only seeing it now as a rabbit, now as a duck (it is never possible to see both at exactly the same time), but coming to the higher order understanding that both perceptions 
are possible, even as only one is available. ${ }^{26}$ When Henry James sat down to read his already published work with a view to revising it, he was viewing it under a different aspect than he had ten or twenty years earlier as he read the original proofs of newly finished novels and stories. This is the force behind the italics in The Golden Bowl Preface, where he described rereading as "an infinitely interesting and amusing act of re-appropriation" (James 1984, 1330).

My first contention in this essay was that we do away with the idea of publication as the one great event, the "Fall", in the life of any text, before which it is private to the author, flexible, and full of compositional possibilities; after which it is public, fixed as a text (though liable to corruption), and open for hermeneutic interpretation. Anyone who doubts that we interpret early drafts in light of later ones, as surely as we accommodate roads not taken (e.g. Eliot's initial title for The Waste Land, "He Do the Police in Different Voices") in reading final versions, should take stock of the number of researchers in rare book rooms who bring a Penguin Classic or Loeb or variorum to the archive. My second aim was to advocate caution in judging the meaning or finishedness of a document from its visual appearance alone. Related to these principles is a modest appeal on behalf of the critical reader. To describe the fugitive possibilities in one manuscript, digitize a whole lot of manuscripts, or publish a reading text for college-level students are acts of re-appropriation. Variance is not something that lies inertly "out there", in the library archive, the bad quarto, the annotated typescript, or the variorum edition, after the event of the brilliant revision or the posthumous re-publication: it is also a critical construction after the fact, a description of various paths that were entertained (even if only briefly) in making what we judge to be a single journey.

\section{Bibliography}

Ackerley, C. J. 2007. T. S. Eliot: "The Love Song of J. Alfred Prufrock" and The Waste Land. Tirril: Humanities EBooks.

26 "Seeing as" is, in fact, "not part of perception" for Wittgenstein, and the "flashing of an aspect on us seems half visual experience, half thought" (1953, 197e). 
Aiken, Conrad. 1967. "An Anatomy of Melancholy". In Allen Tate (ed.), T. S. Eliot: The Man and His Work. London: Chatto and Windus, pp. 194-202.

Barthes, Roland. 1977. "The Death of the Author". In ImageMusic-Text. Trans. and ed. Stephen Heath. London: Fontana, pp. 142-48.

Bowers, Fredson. 1975. Essays in Bibliography, Text, and Editing. Charlottesville: University Press of Virginia.

Bradley, Sculley et al., eds. 1980. "Preface". In Walt Whitman. Poems, 1855-1856. Vol 1 of Leaves of Grass: A Textual Variorum of the Printed Poems. Eds. Sculley Bradley et al. New York: New York University Press, pp. Ix-xiii.

Bundtzen, Linda. K. 2001. The Other Ariel. Amherst: University of Massachusetts Press.

Deleuze, Gilles. 1989. Masochism: Coldness and Cruelty. Trans. Jean McNeil. New York: Zone.

Deppman, Jed, Daniel Ferrer and Michael Groden, eds. 2004. Genetic Criticism: Texts and Avant-textes. Philadelphia: University of Pennsylvania Press.

Doody, Margaret Anne. 1991. Review of Henry James and Revision, by Philip Horne. London Review of Books, 21 March 1991, pp. 16-17.

Dover, Adrian. 2003. "Reprints of Henry James Novels: A checklist". In The Ladder: A Henry James Website, <http://www.henryjames.org.uk/novels/reprints.htm>.

Eliot, T. S. 1957. On Poetry and Poets. London: Faber and Faber.

- - 1971. The Waste Land: A Facsimile and Transcript of the Original Drafts Including the Annotations of Ezra Pound. Ed. Valerie Eliot. London: Faber and Faber.

- - 2005. The Annotated Waste Land with Eliot's Contemporary Prose. Ed. Lawrence Rainey. New Haven: Yale University Press.

- - 2009a. The Letters of T. S. Eliot: Vol. 1, 1899-1922. Rev. ed. Eds. Valerie Eliot and Hugh Haughton. London: Faber and Faber.

- - 2009b. The Letters of T. S. Eliot: Vol. 2, 1923-1925. Eds. Valerie Eliot and Hugh Haughton. London: Faber and Faber. Froula, Christine. 1984. To Write Paradise: Style and Error in Pound's Cantos. New Haven: Yale University Press. 
- - 1996. "Corpse, Monument, Hypocrite Lecteur: Text and Transference in the Reception of The Waste Land". Text: An Interdisciplinary Journal of Textual Studies, 6, pp. 297-314.

Gabler, Hans Walter. 1986. "Afterword". In James Joyce. Ulysses: A Critical and Synoptic Edition. Eds. Hans Walter Gabler, Wolfhard Steppe and Claus Melchior. New York and London: Garland, pp. 1859-1907.

Gardner, Helen. 1972. "The Waste Land" 1972: The Adamson Lecture. Manchester: Manchester University Press.

Ginsberg, Allen. 1987. Howl: Original Draft Facsimile, Transcript \& Variant Versions, Fully Annotated by Author etc. Ed. Barry Miles. Harmondsworth: Viking.

Gosse, Edmund. 1922. Aspects and Impressions. London: Cassell. Greetham, David. 1994. Textual Scholarship: An Introduction. London and New York: Garland.

Greg, W. W. 1927. The Calculus of Variants: An Essay on Textual Criticism. Oxford: Clarendon.

Haffenden, John. 2007 "Vivien Eliot and The Waste Land: The Forgotten Fragments". P. N. Review, 33(5), pp. 18-23.

Halperin, John. 1996. "Henry James's Civil War". The Henry James Review, 17(1), pp. 22-29,

Hay, Louis. 2004. "Genetic Criticism: Origins and Perspectives". In Jed Deppman, Daniel Ferrer and Michael Groden, eds. Genetic Criticism: Texts and Avant-textes. Philadelphia: University of Pennsylvania Press, pp. 17-27.

Hughes, Frieda. 2004. "Foreword". In Sylvia Plath. Ariel: The Restored Edition: A Facsimile of Plath's Manuscript, Reinstating her Original Selection and Arrangement. London: Faber and Faber, pp. xi-xxi.

Hughes, Ted. 1989. "Introduction". In Sylvia Plath. Collected Poems. London Faber and Faber.

- - 1995. "The Art of Poetry No. 71: Interviewed by Drue Heinz. The Paris Review, 134, <http://www.theparisreview.org/ interviews/1669/the-art-of-poetry-no-71-ted-hughes>.

James, Henry. "The Middle Years". Scribner's Magazine, 13 (1893), pp. 609-620.

- - 1895. Terminations. London: William Heinemann.

- - 1984. Henry James: Literary Criticism. Ed. Leon Edel. New York: Library of America. 
Lejeune, Phillippe. 2004. "Auto-Genesis: Genetic Studies of Autobiographical Texts". In Jed Deppman, Daniel Ferrer and Michael Groden, eds. Genetic Criticism: Texts and Avant-textes. Philadelphia: University of Pennsylvania Press, pp. 193-217. Lesser, Zachary. 2004. Renaissance Drama and the Politics of Publication: Readings in the English Book Trade. Cambridge: Cambridge University Press.

Mahaffey, Vicki. 1991. "Intentional Error: The Paradox of Editing Joyce's Ulysses". In George Bornstein, ed. Representing Modernist Texts: Editing as Interpretation. Ann Arbor: University of Michigan Press, pp. 171-91.

McCleery, Alistair. 2006. "Collating the Pirate and the Professionals: Preliminary Analysis of the Texts of Ulysses 1927-34", Genetic Joyce Studies, 6, <http://www.geneticjoycestudies.org/ GJS6/GJS6McCleery.htm>.

McCue, Jim. 2012. "Dilemmas and Decisions in Editing Eliot". Literary Imagination, 14(1), pp. 2-24.

McGann, Jerome J. 1983. A Critique of Modern Textual Criticism. Chicago: University of Chicago Press.

McKerrow, R. B. 1939. Prolegomena to the Oxford Shakespeare. Oxford: Clarendon.

Patterson, Annabel. 1988. "Back by Popular Demand: The Two Versions of Henry V", Renaissance Drama, 19, pp. 29-62.

Pitman, Isaac. 1893. A Manual of the Typewriter London: Pitman. Pope, Alexander. 1751. "Preface to the Works of Shakespear." In Alexander Pope. The Miscellaneous Pieces in Verse and Prose. Vol. 6 of The Works of Alexander Pope Esq. London: J and P Knapton, pp. 394-416.

Ricks, Christopher. 1988. T. S. Eliot and Prejudice. London: Faber and Faber.

Roberts, Gerald, ed. 1995. Gerard Manley Hopkins: The Critical Heritage. London: Routledge.

Plath, Sylvia. 1989. Collected Poems. London: Faber and Faber.

- - 2004. Ariel: The Restored Edition: A Facsimile of Plath's Manuscript, Reinstating her Original Selection and Arrangement. London: Faber and Faber.

Shakespeare, William. 1733. The Works of Shakespeare, Volume the Fourth. Ed. Lewis Theobald. London: A. Bettesworth et al. 
Sullivan, Hannah. 2013. The Work of Revision. Cambridge, Mass.: Harvard University Press.

Valéry, Paul. 1919. "Notes et digression”. In Paul Valéry. Introduction à la méthode de Léonard de Vinci. Paris: Éditions de la Nouvelle Revue Française, pp. 9-41.

- - 1972. "Note and Digression". In Paul Valéry. Masters and Friends. Vol. 9 of The Collected Works of Paul Valéry. Malcolm Cowley and James R. Lawlor. London: Routledge Kegan Paul, pp. 64-109.

Van Hulle, Dirk and Mark Nixon. 2015. "Editorial Principles and Practice". In Dirk Van Hulle and Mak Nixon, eds. The Samuel Beckett Digital Manuscripts Project. Brussels: University Press Antwerp, <http://www.beckettarchive.org/editorial.jsp>

Wagner-Martin, Linda. 1997. “Introduction”. In Linda WagnerMartin, ed. Sylvia Plath: The Critical Heritage. London: Routledge, pp. 1-24.

Wittgenstein, Ludwig. 1953. Philosophical Investigations. Trans. G.E.M. Anscombe. Oxford: Blackwell.

Yeats, W. B. 1957. The Variorum Edition of the Poems of W. B. Yeats. Eds. Peter Allt and Russell Alspach. New York: Macmillan. 